Journal STAND: Sports and Development

http://jurnal.unipasby.ac.id/index.php/stand/about/submissions

jurnal.stand@unipasby.ac.id

\title{
MENINGKATKAN KETRAMPILAN PASSING BAWAH BOLAVOLI MELALUI METODE PEMBELAJARAN TGFU
}

\author{
Mecca Puspitaningsari1 ${ }^{1)}$, Abdul Aziz2 ${ }^{2)}$, Inneke Oktaviani3 ${ }^{3)}$ \\ ${ }^{1}$ Program Studi Pendidikan Jasmani, (STKIP PGRI) Jombang \\ Email: mecca27.stkipjb@gmail.com, \\ ${ }^{2}$ SMP NEGERI 1 TEMBELANG JOMBANG \\ Email: Aajizz01@gmail.com \\ ${ }^{3}$ Pendidikan Jasmani (STKIP PGRI JOMBANG) \\ Email: innekeop@gmail.com
}

\begin{tabular}{l}
\hline Artikel Info \\
\hline Koresponden penulis: Mecca \\
Puspitaningsari1 \\
Email. mecca27.stkipjb@gmail.com \\
$\square$ Diterima 11 Juli 2021 \\
$\square$ Direview 12 Juli 2021 \\
$\square$ Disetujui 16 Juli 2021 \\
$\square$ Dipublikasi 17 Juli 2021
\end{tabular}

Kata Kunci:

Hasil Belajar, TGFU, Passing Bawah Bolavoli.

\begin{abstract}
Abstrak
Penelitian ini bertujuan untuk mengetahui peningkatan hasil belajar passingbawah bolavoli dengan menggunakan pendekatan pembelajaran TGfU (Teaching Games for Understanding) pada siswa kelas VIII SMPN I Tembelang. Penelitian ini menggunakan kajian tindakan atau PTK (penelitian Tindakan Kelas. Adapun empat tahapan dalam penelitian tindakan kelas ini, yaitu perencanaan, pelaksanaan, pengamatan, dan refleksi. Subyek penelitian tindakan kelas ini adalah seluruh siswa kelas VIII dengan jumlah siswa 32 di SMP Negeri 1 Tembelang. Untuk pengambilan data mengunakan instrumen berupa tes keterampilan passing bawah wall volley test (memantulkan bola ke tembok) serta lembar aktifitas guru dan siswa.
\end{abstract}

\section{Abstract}

This study aims to determine the improvement of volleyball bottom passing learning outcomes by using the TGfU (Teaching Games for Understanding) learning approach in class VIII SMPN I Tembelang. This study uses an action study or CAR (Classroom Action Research. There are four stages in this classroom action research, namely planning, implementation, observation, and reflection. The subjects of this classroom action research are all students of class VIII with a total of 32 students at SMP Negeri 1 Tembelang For data collection using instruments in the form of a wall volley test (bouncing the ball against the wall) and teacher and student activity sheets.

\footnotetext{
Keywords:

Learning Outcomes, TGFU, Passing

Volleyball.
} 


\begin{tabular}{|c|c|}
\hline & Journal STAND: Sports and Development \\
umipa Sumalmya & $\frac{\text { http://jurnal.unipasby.ac.id/index.php/stand/about/submissions }}{\text { jurnal.stand@unipasby.ac.id }}$
\end{tabular}

\section{PENDAHULUAN}

Bolavoli adalah olahraga yang dimainkan oleh dua tim dan setiap tim terdiri dari enam pemain, tim tersebut misalnya A dan tim B untuk memulai permainan, tim pertama yang akan melakukan servis dipilih melalui "lempar koin" server (permainan yang melakukan servis) misalnya dari tim A melempar bola ke udara dan kemudian memukulnya sehingga melampaui net dan mendarat di area tim $B$, tim $B$ harus mengembalikan bola tersebut ke area tim A (yang melakukan servis) dengan tidak lebih dari 3 kali melakukan sentuhan terhadap bola, dan 3 kali sentuhan tersebut tidak di lakukan oleh seorang pemain secara berurutan. Demikian seterusnya sampai bola terjatuh ke lantai atau tanah, (Asepta, 2008: 7).

Berdasarkan hasil observasi di SMPN I Tembelang di dapatkan data dari penguasaan ketrampilan passingbawah bolavoli pada siswa kelas VIII dari 32 siswa yang mendapatkan nilai kurang sejumlah 20 siswa, nilai cukup 6 siswa, dan nilai baik 6 siswa. Hal itu dibuktikan dengan hasil dari kegiatan pra siklus. Berdasarkan RPP yang digunakan oleh guru, guru menggunakan metode pembelajaran langsung, dan juga tanpa adanya refleksi guru terhadap aktivitas pembelajaran yang sudah dilaksanakan, terutama pada materi passingbawah bolavoli siswa kelas VIII SMPN I Tembelang. Menindak lanjuti permasalahan tersebut, maka dalam rangka meningkatkan keterampilan passing bawah pada siswa kelas
VIII SMPN I Tembelang, peneliti menerapkan salah satu cara, dengan menggunakan pendekatan model pembelajaran TGfU (Teaching Games For Understanding) pada saat pembelajaran bolavoli passing bawah.

\section{KAJIAN LITERATUR DAN PENGEMBANGAN HIPOTESIS}

Menurut (Rusdiani, 2013: 137) pendidikan jasmani dan kesehatan, adalah proses pendidikan yang memanfaatkan aktivitas jasmani yang direncanakan secara sistematik bertujuan untuk mengembangkan dan meningkatkan individu secara organik, neuromuskuler, perseptual, kognitif, dan emosional, dalam kerangka system pendidikan nasional. Mata pelajaran pendidikan jasmani, olaraga, dan kesehatan bertujuan agar peserta didik memiliki kemampuan sebagai berikut:

1) Mengembangkan keterampilan pengelola diri dalam upaya mengembangkan dan memelihara kebugaran jasmani serta pola hidup sehat melalui berbagai aktivitas jasmani dan olaraga yang terpilih,

2) Meningkatkan pertumbuhan fisik dan pengembangan psikis yang lebih baik,

3) Meningkatkan kemampuan dan keterampilan gerak dasar,

4) Meletakkan landasan karakter moral yang kuat melalui internalisasi nilai - nilai yang terkadung didalam pendidikan jasmani, olaraga, dan kesehatan,

5) Mengembangkan sikap sportif, jujur, disiplin, bertanggung jawab, kerjasama, percaya diri demokrasi, 


\begin{tabular}{|c|c|}
\hline & Journal STAND: Sports and Development \\
umipa Sumalmya & $\frac{\text { http://jurnal.unipasby.ac.id/index.php/stand/about/submissions }}{\text { jurnal.stand@unipasby.ac.id }}$
\end{tabular}

6) Mengembangkan keterampilan untuk menjaga keselamatan diri sendiri, orang lain dan lingkungan,

7) Memahami konsep aktivitas jasmani dan olaraga dilingkungan yang bersih sebagai informasi untuk mencapai pertumbuhan fisik yang sempurna, pola hidup sehat dan kebugaran, terampil, serta memiliki sifat yang positif.

Bola voli adalah merupakan salah satu materi dari olahraga bola besar. Teknik dasar dalam bola voli antara lain passing, servis, smash, blocking. Bola voli adalah olahraga yang dimainkan oleh dua tim dan setiap tim terdiri dari enam pemain, tim tersebut misalnya A dan tim B.untuk memulai permainan, tim pertama yang akan melakukan servis dipilih melalui "lempar koin" server (permainan yang melakukan serve) misalnya dari tim $\mathrm{A}$ melempar bola ke udara dan kemudian memukulnya sehingga melampaui net dan mendarat di area tim B. Tim B harus mengembalikan bola tersebut ke area tim A (yang lemakukan serve) dengan tidak lebih dari 3 kali melakukan sentuhan terhadap bola, dan 3 kali sentuhan tersebut tidak di lakukan oleh seorang pemain secara berurutan. Demikian seterusnya sampai bola terjatuh ke lantai atau tanah. Permainan bola voli akan berlanjut sampai salah satu tim memperoleh skor sebanyak 25 poin. Tim yang pertama memperoleh skor 25 poin adalah tim yang memenangkan set tersebut. Tim yang memenangkan 2 set permainan lebih dulu adalah tim yang memenangkan pertandingan bola voli tersebut (Asepta, $2008: 8$ ).

Pembelajaran Pendekatan Taktik adalah sebuah pendekatan yang berpusat pada siswa dan permainan untuk pembelajaran permainan yang berkaitan dengan olah raga dengan hubungan yang kuat dengan sebuah pendekatan konstruktifis dalam pembelajaran. Dua dekade telah terlewati sejak pertama kali Pembelajaran Pendekatan Taktik diperkenalkan dalam Bulletin of Physical Education (oleh Bunker dan Thorpe pada 1982 dan oleh Thorpe, Bunker, dan Almond pada 1984)

Gambaran model Pembelajaran Pendekatan Taktik ini meliputi perkenalan tentang model orisinil, diskusi tentang prinsip-prinsip pemandu, dan eksplorasi dari berbagai macam kegiatan dan ide yang membentuk perkembangan model. Model Pembelajaran Pendekatan Taktik menggeser pengajaran permainan dari sebuah pendekatan yang berbasis perkembangan teknik atau konten dengan pelajaran yang sangat terstruktur ke pendekatan yang lebih berbasis pada siswa yang berhubungan dengan taktik dan kemampuan dalam konteks permainan (Bunker \& Thorpe 1982; Thorpe \& Bunker, 1989).

\section{METODE}

Tindakan Kelas ini dilaksanakan di SMPN I Tembelang kabupaten Jombang. Penelitian Tindakan Kelas ini dilaksanakan pada bulan Maret sampai bulan April 2020. Subjek penelitian ini adalah siswa kelas VIII 


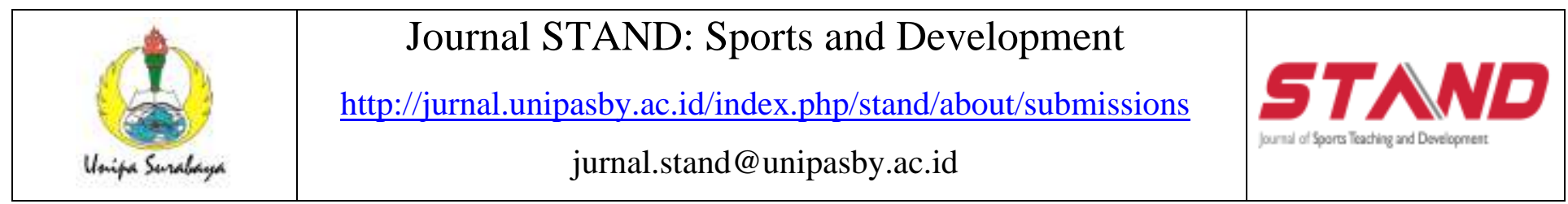

SMPN Tembelang. Tahun Ajaran 2019/2020 yang berjumlah 32 siswa. Dengan rician siswa putra : 20 Anak dan siswa putri : 12 anak. Teknik pengumpulan data dalam Penelitian Tindakan Kelas (PTK) ini terdiri dari :

1. Tes

Dipergunakan sebagai teknik pengumplan data untuk mengukur kemampuan siswa dalam penguasaan materi passing bawah bolavoli.

Untuk memperoleh data hasil penelitian yang berupa peningkatan penguasaan passing bawah digunakan instrument berupa tes keterampilan passing bawah wall volley test memantulkan bola ketembok (Mutohir, 2013: 32).

Untuk memperoleh data hasil penelitian yang berupa peningkatan penguasaan passing bawah digunakan instrument berupa tes keterampilan passing bawah wall volley test memantulkan bola ketembok (Mutohir, 2013: $32)$.

Untuk lebih jelasnya dapat dilihat pada gambar berikut :

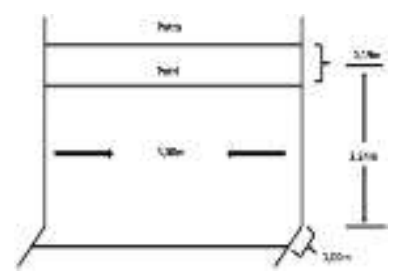

Gambar 3.2 Bentuk lapangan (memantulkan) bola ke dinding

( Sumber : Yunus, 1992 : 205).

$$
\text { Rumus yang digunakan untuk }
$$
menentukan nilai akhir sebagai berikut :

$$
\text { Nilai }=\frac{\text { Total nilai }}{\text { Nilai maksimal }} \times 100
$$

Setelah ditentukan nilai akhir pretest dan postest, langkah selanjutnya adalah menganalisis data ke dalam norma penilaian. Norma penilaian yang dimaksud adalah untuk menentukan kategorisasi terhadap hasil tes. Kategorisasi yang dimaksud adalah sebagai berikut :

a) Mendapat nilai sangat baik, jika skor nilai akhir antara $=91-100$

b) Mendapat nilai baik, jika skor nilai akhir antara $=81-90$

c) Mendapat nilai cukup, jika skor nilai akhir antara $=71-80$

d) Mendapat nilai kurang, jika skor nilai akhir antara $=61-70$

e) Mendapat nilai kurang sekali, jika skor nilai akhir $=\leq 60$

2. Observasi

Digunakan sebagai teknik untuk mengumpulkan data tentang aktivitas siswa dalam mengikuti proses belajar mengajar saat penerapan Teaching Game for Understanding (TGfU). 


\begin{tabular}{|c|c|}
\hline & Journal STAND: Sports and Development \\
umipa Sumalmya & $\frac{\text { http://jurnal.unipasby.ac.id/index.php/stand/about/submissions }}{\text { jurnal.stand@unipasby.ac.id }}$
\end{tabular}

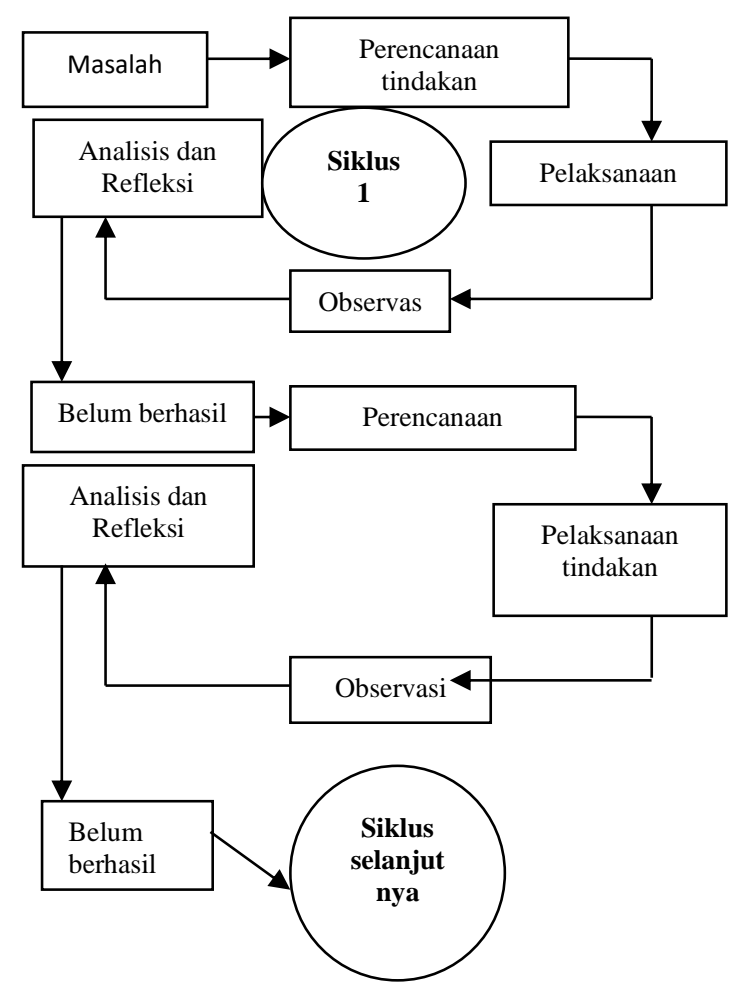

Gambar 3.1 Siklus Penelitian Tindakan Kelas (Maksum, 2012:95)

\section{HASIL DAN PEMBAHASAN}

Pada kegiatan pra siklus, dilaksanakan tindakan berupa pembelajaran yang menggunakan metode demonstrasi. Kegiatan pra siklus ini dilakukan untuk mengetahui hasil belajar, aktifitas guru, dan aktifitas siswa sebelum dilakukan tindakan pembelajaran menggunakan metode Teaching Games for Understanding (TGfU). Dari pelaksanaan tindakan pra siklus, hasil belajar siswa menunjukkan dari 32 siswa, terdapat 11 siswa yang nilainya diatas kriteria ketuntasan minimal. Selain itu, pada kegiatan pra siklus prosentase aktifitas guru dalam mengajar sebesar 59,37\%, dan prosentase aktifitas siswa dalam pembelajaran sebesar 53,12\%.
Pada siklus I dilaksanakan tindakan berupa pembelajaran passing bawah individu dan berpasangan. Pembelajaran ini bertujuan untuk pemahaman siswa tentang keterampilan passing bawah yang benar. Dari pelaksanaan tindakan yang telah dilakukan pada siklus I, tingkat kemampuan siswa menunjukkan dari 32 siswa, terdapat 23 siswa yang nilainya diatas kriteria ketuntasan minimal. Selain itu, pada kegiatan siklus I prosentase aktifitas guru dalam mengajar sebesar $72 \%$, dan prosentase aktifitas siswa dalam pembelajaran sebesar $68,75 \%$. Pada kegiatan siklus I, aktifitas guru dan siswa sudah mengalami peningkatan namun belum mencapai target yang diinginkan peneliti. Hal ini dikarenakan masih terdapat hambatan-hambatan yang ada pada siklus I.

Pada siklus ke II adalah perbaikan dari siklus pertama, pada siklus ini ada sedikit perubahan pada tindakan, peneliti menambahkan sebuah permainan passing bawah berkelompok. Permainan ini bertujuan untuk meningkatkan keterampilan passing bawah siswa dan keaktifan siswa dalam mengikuti pembelajaran. Dari pelaksanaan tindakan siklus II, peningkatan keterampilan dari 32 siswa, terdapat 28 siswa yang nilainya diatas kriteria ketuntasan minimal. Selain itu, pada kegiatan siklus II, prosentase aktifitas guru dalam mengajar sebesar $87,50 \%$, dan prosentase aktifitas siswa dalam pembelajaran sebesar $84,37 \%$. Hal ini sejalan dengan adanya perubahan perilaku siswa yang menunjukkan 


\begin{tabular}{|c|c|c|}
\hline & Journal STAND: Sports and Development \\
umipa Sumalaya & http://jurnal.unipasby.ac.id/index.php/stand/about/submissions \\
\hline
\end{tabular}

keaktifan dalam mengikuti proses pembelajaran dengan baik.

Berikut diagram hasil ketuntasan pembelajaran passing bawah bolavoli siswa kelas VIII B SMP Negeri 1 Tembelang Jombang tahun pelajaran 2019/2020 mulai dari pra-siklus hingga ke siklus II.

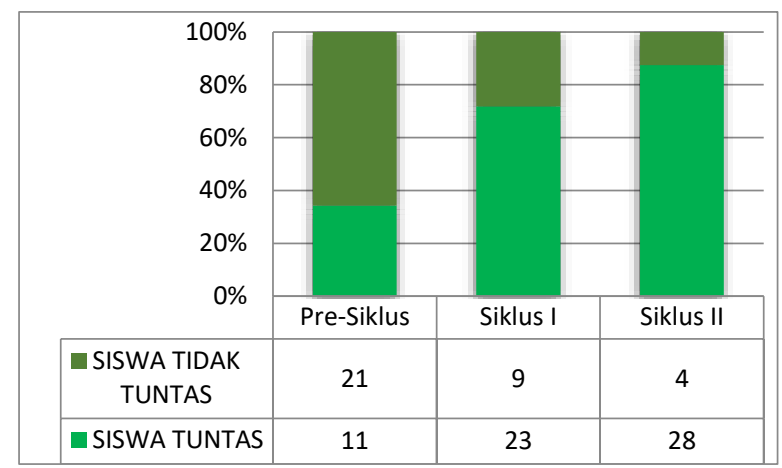

Gambar 4.4 Grafik Ketuntasan Belajar Siswa

\section{KESIMPULAN}

Kesimpulan dalam penelitian ini bahwa dengan menerapkan metode pembelajaran Teaching Games for Understanding (TGfU) pada siswa kelas VIII B SMP Negeri I Tembelang, secara bertahap dapat meningkatkan keterampilan passing bawah bolavoli, berdasarkan data dari prosentase yang dihasilkan Pra-siklus, Siklus I sampai dengan siklus II. Prosentase peningkatan keterampilan passing bawah bolavoli siswa pada siklus I mencapai $72 \%$ dan pada siklus II mencapai $87 \%$

\section{REFERENSI}

Arikunto, Suharsimi. 2010. Prosedur Penelitian Suatu Pendekatan Praktis. Jakarta: PT Rineka Cipta.
Griffin, Linda L. (2005). Model Pembelajaran Pendekatan Taktik: Teori, Penelitian, dan Praktik. (Alih bahasa: Soni Nopembri, Saryono, \& Ahmad Rithaudin). Yogyakarta: FIK UNY.

Harsuki, H. 2013. Pengembangan Olahraga Terkini. Jakarta: Raja Grafindo Persada.

Maksum, Ali. 2007. Diktat Statistik dalam Olahraga. Surabaya: Unesa University Press.

Maksum, Ali. 2012. Metodologi Penelitian Dalam Olahraga. Surabaya: Unesa University Press.

Mudjiono dan Dimyati. 2011. Belajar dan Pembelajaran. Jakarta: PT Rineka Cipta.

Mutohir. 2013. Permainan Bolavoli Konsep Teknik Strategi dan Modifikasi. Jakarta: Graha Pustaka Media Utama

Ngalimun. 2015. Strategi dan Model Pembelajaran. Yogyakarta: Aswaja Pressindo

Permana, Asepta Yoga. 2008. Bermain dan Olahraga Bola Voli. Surabaya: Insan Cendekia.

Rosdiani, Dini. 2013. Perencanaan Pembelajaran Dalam Pendidikan Jasmani dan Kesehatan. Bandung: CV Alfabeta.

Sudjana, Nana. 2014. Penilaian Hasil Proses Belajar Mengajar. Bandung:Rosda Karya.

Suprijono. 2009. Cooperative learning. Bandung : Rosda Karya.

Trianto. 2007. Model Pembelajaran Terpadu dalam Teori dan Praktek. Jakarta: PT. Prestasi Pustaka.

Winarno. 1995. Belajar Motorik. Malang: Departemen Pendidiksn Dan Kebudayaan Institut Keguruan Dan Ilmu Pendidikan Malang Proyek Operasi Dan Perawatan Fasilitas. 


\begin{tabular}{|c|c|c|}
\hline & Journal STAND: Sports and Development \\
Unima Sumalay. & $\frac{\text { http://jurnal.unipasby.ac.id/index.php/stand/about/submissions }}{\text { jurnal.stand @ unipasby.ac.id }}$
\end{tabular}

Yunus. 1992. Olahraga Pilihan Bola Voli.

Departemen Pendidikan dan Kebudayaan

Derektorat Jenderal Pendidikan Tinggi

Proyek Pembinaan Tenaga Kependidikan. 